This PDF is a selection from an out-of-print volume from the National Bureau of Economic Research

Volume Title: The Effects of U.S. Trade Protection and Promotion Policies

Volume Author/Editor: Robert C. Feenstra, editor

Volume Publisher: University of Chicago Press

Volume ISBN: 0-226-23951-9

Volume URL: http://www.nber.org/books/feen97-1

Conference Date: October 6-7, 1995

Publication Date: January 1997

Chapter Title: Carwars: Trying to Make Sense of U.S.-Japan Trade Frictions in the Automobile and Automobile Parts Markets

Chapter Author: James Levinsohn

Chapter URL: http://www.nber.org/chapters/c0307

Chapter pages in book: (p. 11 - 32) 


\title{
1 \\ Carwars: Trying to Make Sense of U.S.-Japan Trade Frictions in the Automobile and Automobile Parts Markets
}

\author{
James Levinsohn
}

Sometimes, the line between trade promotion and trade protection is a fuzzy one. This is especially true in the automobile industry. For example, in an apparent effort to induce Japan to buy more U.S. cars and car parts, the United States recently threatened 100 percent tariffs on a handful of Japanese luxury cars. Trade promotion or trade protection?

The debate on U.S.-Japan trade promotion and trade protection in the automobile industry is frequently heated and pitched. The goal of this paper is to make sense of the sequence of recent events in which the United States developed a large bilateral trade deficit in automobile parts with Japan, which then led to the threatened tariffs on Japanese luxury cars, which in turn led to Japanese promises to buy more U.S. parts. Along the way, some of the questions addressed are the following: What are the root causes of the U.S. trade deficit in automobile parts? Why did the United States target thirteen luxury cars produced by Japan instead of a more broadly based tariff or a tariff on automobile parts? How would the profits of domestic, Japanese, and European firms have been affected by the proposed 100 percent tariff? How much of the tax burden would have been borne by U.S. consumers and how much by the Japanese firms? Readers should note, however, that this paper does not attempt to resolve the "big-picture" issue of how closed the Japanese automobile market may be.

The paper is organized as follows. Section 1.1 addresses the question of how the United States and Japan came to the brink of a trade war in the summer of

James Levinsohn is professor of economics and of public policy at the University of Michigan and a research associate of the National Bureal of Economic Research.

The author is grateful to Steven Berry, Edward Leamer, Ariel Pakes, and Amil Petrin for many helpful conversations, to Amil Petrin for research assistance, and to Mike Hewitt for background research assistance. 
1995. This section discusses how structural differences in the U.S. and Japanese automobile parts industries may have contributed to trade frictions. Section 1.2 analyzes the logic (such as it was) that led from the parts dispute to the threatened tariff. Section 1.3 analyzes the likely consequences of the threatened tariff using a detailed econometric model of industry equilibrium. Conclusions are gathered in section 1.4.

\subsection{Trade Promotion and Trade Protection in the 1990s: How Did We Get to Where We Are?}

Trying to understand the sequence of events that led to the threatened 100 percent tariffs on thirteen Japanese luxury cars is tricky business, for logic, analysis, and common sense will get one only so far. On the surface, what began as a dispute about how many parts the Japanese should buy from U.S. parts manufacturers led to a threatened tariff on Japanese luxury cars and resulted, in the end, in Japanese promises to buy more U.S. parts. How was it that these events came to pass?

The very notion that trade in automobile parts could lead to a major trade dispute is indicative of the large changes the automobile industry has undergone in the last ten years. Not that long ago, Japanese cars were made in Japan, and American cars were made in the United States. Suppliers to the assemblers were located close to the assembly factories as transport costs mattered. U.S. assemblers dealt mostly with U.S. parts manufacturers, and the same was true in Japan. There simply was not a lot of international trade in automobile parts.

By the mid-1980s, the volume of trade began to increase. Table 1.1 gives the U.S.-Japan trade balance in automobile parts for 1985-94. In that period, the U.S.-Japan bilateral trade deficit in automobile parts went from about $\$ 3$ billion to almost $\$ 13$ billion. This section discusses the role that industry structure might have played in explaining the figures in table 1.1.

Table 1.1

U.S.-Japan Trade in Automobile Parts, 1985-94 (in \$million)

\begin{tabular}{cccc}
\hline Year & Imports of Parts & Exports of Parts & Balance \\
\hline 1985 & 3,280 & 200 & $-3,080$ \\
1986 & 6,220 & 224 & $-5,996$ \\
1987 & 7,586 & 259 & $-7,327$ \\
1988 & 9,293 & 451 & $-8,842$ \\
1989 & 10,595 & 619 & $-9,976$ \\
1990 & 10,410 & 871 & $-9,539$ \\
1991 & 9,960 & 826 & $-9,134$ \\
1992 & 10,816 & 1,035 & $-9,781$ \\
1993 & 12,339 & 1,130 & $-11,209$ \\
1994 & 14,334 & 1,485 & $-12,849$ \\
\hline
\end{tabular}

Source: U.S. Census Bureau. 


\subsubsection{Industry Structure in the United States and Japan}

The relations between assemblers and their parts suppliers differed in the United States and Japan, and this is largely a product of history. The ways in which they differed have important implications for the deficit observed in the later years in table 1.1.

First, consider the structure of the U.S. automobile parts industry. In the United States, there was a long history of vertical integration in the automobile industry. At one extreme was Henry Ford's River Rouge plant, where it was loosely claimed that iron ore went in one end and cars came out the other. While the three U.S. automobile manufacturers have moved from this extreme, the industry is still quite vertically integrated. Consequently, many parts are still supplied by in-house suppliers.

At least until recently, the U.S. assemblers' relations with their suppliers were, at best, complicated. As explained in more detail in Womack, Jones, and Roos (1990), U.S. assemblers frequently supplied their potential parts manufacturers with detailed specifications of a particular part and then took bids based on price for a specified quantity. This emphasis on price did little to encourage capital investment and, especially, research and development by the suppliers. The emphasis on price is also sometimes claimed to have negatively affected the quality of contracted parts. Future price adjustments and negotiations were standard, and the ensuing relation was seldom one of cooperation. U.S. firms also purchased imported parts, and this practice was facilitated by stockpiling parts inventories. That is, in order to insure against parts becoming unavailable, U.S. firms would keep hefty inventories of parts. Hence, while transport costs would add to the cost of an imported part, the delays inherent in international shipping were not likely to be terribly costly, for inventories were available to buffer these delays. All these practices are changing, but understanding them helps explain some of the current issues in the automobile parts dispute.

The relation between Japanese automobile assemblers and their parts suppliers differs from the traditional relation in the U.S. industry. Japanese automobile assemblers are reputed to have developed a more long-term relation with their suppliers. The reasons for this are many, but they are due in part to historical as well as economic influences. Following World War II, Japanese automakers had a series of sequential decisions to make. They needed to decide whether to source parts domestically or through imports. Owing to stringent exchange controls and rules on imports following the war, they chose the former option. They then needed to decide whether to make their parts themselves or buy from outside sources. They chose not to adopt the U.S. pattern of vertical integration, this was probably due in part to the scarcity of capital following the war, in part to the lower wage structure that was prevalent among the parts suppliers, and in part to a strategy to lower investment risks (by limiting vertical integration, less capital was at risk). 
Japanese OEMs (original equipment manufacturers) next needed to decide whether to seek either stable or floating relations with their suppliers and whether to make these relationships exclusive. When the Japanese OEMs realized their great dependence on outside suppliers, they anticipated several potential difficulties. First, some of their suppliers had a low level of technological competence. Second, with too many suppliers, any one supplier would have difficulty achieving economies of scale. Third, the cost of policing the OEMsupplier relation might be formidable. Certain criteria were established for suppliers. For example, potential suppliers were closely examined with regard to their reliability, financial soundness, and capacity to learn the necessary technology quickly. Also, the relations with suppliers had to last long enough to justify the large expenses encountered while screening different suppliers. Finally, the technological assistance and actual technology given to the supplier had to be kept out of the hands of rivals. These criteria led to the development of long-term exclusive relations with parts suppliers. For purposes of comparison, it is estimated that in 1987 a Japanese OEM would, on average, deal directly with two to three hundred parts makers (not including materials and equipment makers), while a comparable number for General Motors was in the range of up to thirty-five hundred (Mitsubishi Research Institute 1987).

The resulting structure of the parts industry in Japan resembled a pyramid in which the OEM was on the top, followed by first-tier suppliers. These firsttier suppliers were often controlled by the OEM through equity holdings, and, in any case, the OEM and the first-tier supplies typically developed a very close and long-standing working relation.

\subsubsection{Implications for Trade Patterns}

The different market structures in the automobile parts markets in Japan and the United States had implications for the pattern of international trade. In particular, the structure of the Japanese industry made it difficult for U.S. firms to sell there, while the Japanese were more successful selling in the United States. The reasons that U.S. firms had such small sales in Japan are often categorized under the catch-all term structural impediments. Four such examples are discussed below.

First, U.S. parts suppliers have traditionally relied on fully spelled-out blueprints, while Japanese OEMs often work closely with their suppliers on the design of the parts. This poses problems for U.S. parts makers who may not be accustomed to investing in the necessary engineering and design procedures. In particular, without technical centers in Japan, U.S. firms are often at a competitive disadvantage. Even U.S. firms that are accustomed to doing their own design often did not welcome the fact that many Japanese OEMs have contracts that stipulate that they have the right to provide supplier-prepared drawings to other suppliers if the OEM sees fit. Japanese suppliers are more willing to accept such arrangements when their long-term relations with the OEMs are more or less guaranteed. 
Second, the Japanese system of long-term contracts may act as a structural impediment to trade. As the Japanese OEMs invested heavily in their major suppliers in terms of technical knowledge and screening processes for reliability, it became more expensive for the OEMs to switch to another (possibly U.S.) supplier. Another aspect of the contracts that has trade implications concerns the degree of information sharing often required of parts suppliers. While U.S. parts firms are generally accustomed to disclosing only prices and quality standards to the U.S. OEMs, Japanese OEMs expect more complete and open disclosure of costs and profit margins by their suppliers.

Third, the stringent quality guideline that the Japanese OEMs demand may act as a structural impediment to trade. U.S. parts suppliers faced competing influences when supplying domestic OEMs. While they had quality standards to meet, their chances of winning or renewing a contract with the Big Three improved if they could keep their costs very low. This trade-off, combined with often preannounced inspections by the OEM, led some parts makers (quite rationally) to compromise quality. Japanese OEMs treated the quality issue quite seriously. Like costs, the automaker set the objective quality level during the design process. The parts maker then pursued cost targets while maintaining the target quality levels. Rejection rates for Japanese parts suppliers are roughly one in one thousand and are closer to one in ten thousand for parts actually delivered. This heightened level of quality is due to extensive testing and a high degree of factory automation. It is also expensive, and the willingness of the suppliers to undertake this expense is surely related to the longterm nature of contracts.

The fourth and possibly greatest structural impediment to trade is the difference in inventory strategies between the U.S. firms and their Japanese counterparts. While the Big Three have often used inventory stockpiling in an effort to achieve long production runs and to insure against equipment breakdowns, defective parts, and interruptions in parts supplies, Japanese automakers instead rely heavily on a just-in-time (JIT) system. In turn, Japanese OEMs require their suppliers to work within the JIT system. This often means daily deliveries to assembly plants. The deliveries operate within a synchronized system in which parts are recognized by bar codes indicating the model and reference number of the targeted vehicle, the point of delivery, and the hour the vehicle will pass a specified assembly point. While some parts may be delivered only once a day, others such as headlights or batteries may be delivered every two to four hours. This system places great reliance on high parts quality as there are neither inventories nor time to test or inspect shipments. The system works well, but it not conducive to international trade in automobile parts since it requires parts suppliers to be in close geographic proximity to the factory.

These structural impediments are not inconsistent with complaints often heard on behalf of U.S. parts suppliers. Common complaints include an alleged unfair advantage given to Japanese suppliers (see the discussion involv- 
ing the importance of long-term relations above), unreasonable delays in negotiations, difficulty in obtaining information needed for bids, design standards that would require a massive production overhaul by U.S. parts suppliers, and frequent product modification requests.

A final reason why the U.S. did not sell that many parts to Japan while Japan sold more to the U.S. throughout the 1970s and early 1980s lay with the exchange rate. During the 1970 s, the exchange rate ranged from $¥ 200$ to $¥ 350$ per U.S. dollar. This made Japanese components look relatively inexpensive to U.S. OEMs and, combined with the U.S. firms' emphasis on price, made imported parts relatively attractive.

All these reasons help explain the trade imbalance in automobile parts. Regulations in Japan may also have played a role, but much of the evidence here is anecdotal and hard to quantify. For example, U.S. firms that attempted to service the Japanese after market for parts (replacement parts for existing cars) claimed that Japan's strict inspection of used cars limited their ability to compete. Some of these complaints had little to do with the different structures of the U.S. and Japanese industries and instead seem more outrightly protectionist.' It is, however, difficult to judge how important to the parts trade these regulations might be.

Prior to about 1981, the debate on the automobile parts trade was relatively simple even if answers were not obvious. That is, it was well understood that the Japanese did not buy many parts from U.S. suppliers and that this had a lot to do with differing industry structures. Likewise, the U.S. industry structure was more conducive to importing parts.

\subsubsection{New Issues in the Automobile Parts Trade Debate: The VER Years}

In May 198I, Japan agreed to a voluntary export restraint (VER) on exports of automobiles to the United States. This led to an influx of direct foreign investment (DFI) by Japanese automobile manufacturers. By 1985, Honda was producing over 150,000 cars in Marysville, Ohio, and Nissan had started operations in Tennessee. In the years that immediately followed, Toyota, Mazda, and Mitsubishi followed suit. During this same period, the weak yen began to strengthen relative to the dollar. In 1985 , exchange rate was about $¥ 236$ per dollar. By 1994, it was at about $¥ 100$. Finally, by the early 1980 s, the surge in imported automobiles from Japan that occurred in the mid- and late 1970s had aged such that the demand for after market parts for Japanese cars was now increasing. All these phenomena had important implications for the automobile parts trade between the United States and Japan.

As noted above, Japanese OEMs frequently relied on parts suppliers with whom they had long-established working relations. When the OEMs then

1. One (possibly outdated) example was a regulation that required the bulbs in both headlights to be the same brand. 
opened operations in the United States, they hesitated simply to drop their Japanese suppliers and instead buy solely from U.S. parts manufacturers. Hence, with the influx of DFI, some of the parts used in production in the United States were imported from Japan, and this led to an increase in the imports of parts. By definition, it takes a while for new working relations to become established ones. Over time, Japanese firms have indeed established relations with U.S. firms. (A popular advertising campaign for the Toyota Camry points out the many U.S. sources of key components of the Camry). Political pressure and domestic content legislation (real and threatened) surely played a role in getting Japanese OEMs to purchase parts made in the United States, but the dramatic strengthening of the yen was also important. With the exchange rate at $¥ 130$ to the dollar, buying parts in dollars looked much more attractive than doing so when it was at $¥ 230$. Hence, while Japanese OEMs operating in the United States have established relations with U.S. parts suppliers, this took time, and, in the interim, there was increased demand for parts from Japan.

The actual accounting of the automobile parts trade also became both more complicated and less informative in the presence of DFI. Many observers of the automobile parts trade focus on the bilateral trade balance in automobile parts between the United States and Japan. While perhaps a natural figure to focus on, this trade balance hides a great deal in an era with substantial DFI. To see this, consider the following hypothetical example. Suppose that Subaru's new plant in Indiana bought absolutely all its parts from U.S. firmsadmittedly an extreme example. These purchases would not directly show up on the bilateral trade balance since they are domestic transactions. (While Suburu-Japan may end up buying fewer parts in Japan from its Japanese suppliers, this too is not an international transaction.) Hence, while much debate focuses on the bilateral trade balance, substantial changes in industry structure accompanying DFI may not even appear in this balance.

Another new phenomenon in the DFI era is the confusion regarding the very notion of nationality. When Japanese firms used parts made in Japan in OEM plants located in Japan and U.S. firms did analogously, accounting was pretty simple. That simplicity is long gone, and it has been replaced by complex relations that make the very idea of nationality tricky. When the notion of nationality is complex, if not outright confused, discussion of trade policy is similarly complex. As noted above, Japanese OEMs now produce in the United States. Many Japanese parts suppliers have also set up shop in the United States. By 1993, Japanese firms had invested in about 280 U.S. firms in the automobile parts sector. Of these, about half were joint ventures, while the other half were wholly owned subsidiaries. U.S. OEMs now have production facilities in Canada and Mexico, although most production remains in the United States. American parts manufacturers, however, have invested--heavily in some cases-in Mexico. Other parts producers have entered into the joint 
ventures with Japanese parts firms mentioned above. The result is a case in which one American consumer might buy a Toyota assembled in Kentucky with parts from a Japanese-owned firm in Indiana, a U.S.-owned firm in Mexico, a joint U.S.-Japan venture located in Ohio, and a Japanese parts firm in Japan. Using dated nomenclature, this consumer bought a Japanese car. Another consumer might buy a Ford Escort assembled in Hermosillo, Mexico, with parts manufactured by a joint U.S.-Japanese venture in Mexico. Using the same dated nomenclature, this consumer bought an American car. In this environment, discussions of traditional trade policy, which by their very nature are oriented around a well-defined notion of nationality, become both confusing and confused.

While much has changed in this era of DFI, it remains the case that U.S. parts manufacturers sell very little to Japanese OEMs located in Japan. A rough estimate is that U.S. firms have only about 1 percent of the OEM market in Japan. There have been indications, however, that some U.S. firms are making inroads in the Japanese parts market. For example, between 1986 and 1993, TRW saw its annual worldwide sales to Japanese automobile companies increase sevenfold to $\$ 500$ million, accounting for about 10 percent of its total automobile parts sales. TRW initially invested heavily in joint ventures with Japanese companies supplying the U.S. plants of Toyota and Nissan. Once TRW found this niche, it began supplying these firms back in Japan. Except for air bag components and some electronics, TRW makes the products for its Japanese OEMs in Japan, allowing them to participate effectively in the JIT system. Other firms are following suit. Since 1991, GM has operated a technical center in Japan to develop automobile parts, and its components sales in Japan have increased 50 percent since the center opened. In 1993, Ford ACG began operating a technical center for electronic components in Hiroshima, hoping to expand sales to Mazda, Nissan, and Toyota. Ford is also investing $\$ 50$ million in a new technical center near Tokyo expected to open in late 1995 . These changes may lead to a larger U.S. presence in the Japanese parts market, but history suggests that such changes take time.

In 1992, President Bush and the U.S. automakers attempted to hurry matters along with Bush's well-publicized trip to Tokyo. Although the president was criticized for so blatantly pursuing U.S. commercial interests, he did secure a promise from the Japanese to purchase more automobile parts from American companies. Japan pledged to purchase $\$ 19$ billion worth of U.S. automobile parts in fiscal year 1994. Whether owing to this pledge or to the natural course of events, Japanese automakers purchased $\$ 19.9$ billion worth of parts in fiscal year 1994 (Automotive News, 17 July 1995). Most of these purchases $(\$ 15.4$ billion) were parts used in the Japanese firms' transplant operations in the United States. As discussed above, many of these transactions were, from an accounting perspective, domestic transactions between the transplant and the U.S. parts firm. Japan also pledged to purchase $\$ 3.6$ billion worth of parts for 
export to Japan in fiscal year 1994, and it fell about $\$ 0.6$ billion short of this pledge, again suggesting that, in the Japanese automobile parts industry, location matters.

\subsection{Why a Threatened Tariff on Thirteen Japanese Luxury Cars?}

In 1995, President Clinton threatened a 100 percent tariff on thirteen Japanese luxury cars. It is not obvious that any single and narrowly defined issue triggered this threat. Clearly, the United States was concerned about its large bilateral trade deficit with Japan, and automobiles and automobile parts were a large portion of this. But, while the Big Three publicly complained about the difficulty of selling cars in Japan, most industry observers concluded that the Japanese market was not where the Big Three would make their mark in Asia. To be sure, there were significant barriers to selling cars in Japan (as claimed by the Big Three), but, at the same time, it was also the case that the cars that U.S. firms sold were not terribly well suited to the Japanese market. As noted above, the relative merits of these arguments are not addressed in this paper. In either case, the United States was not likely significantly to redress its bilateral trade deficit by exporting large quantities of cars to Japan.

If it were to redress the bilateral trade deficit via the automobile industry trade, the United States was left with three options. It could discourage the import of Japanese cars, encourage the export of U.S. automobile parts, and discourage the import of Japanese automobile parts. The first and third options clearly involve trade protection, while the second involves trade promotion. Pursuing the trade promotion option in this case, absent any sort of threat, would prove difficult. As discussed in the previous section, the structural reasons behind the bilateral trade deficit in automobile parts were deep-rooted. The first and third option provided such a threat, but each of these also posed problems.

Consider first the possibility of tariffs on Japanese automobile parts. The end users of these parts were in some cases American producers and in others transplant firms in the United States. To the extent that U.S. OEMs were using Japanese parts, a tariff would raise their costs-an option not greeted with enthusiasm. ${ }^{2}$ The other end user of imported parts was the transplant factories. But these firms employed U.S. workers, and raising the cost of cars produced by these factories would negatively affect employment. This, too, was not an especially attractive option.

This left the possibility of placing tariffs on Japanese cars. Leaving aside issues involving violation of the GATT and possible actions the World Trade Organization (WTO) might take, tariffs on Japanese cars still posed problems.

2. From an economic viewpoint, higher costs might still impart an advantage to the U.S. firms if their competition faced yet higher costs from the tariff. 
At the heart of these problems was the fact that many of the high-volume Japanese cars were in fact made in the United States. In the data set used in the econometric analysis in the next section, cars sold by Japanese firms in the 1994 calender year totaled 2.65 million (out of total U.S. sales of 8.782 million). Of these, 1.793 million are cars whose nameplate was produced in the United States. Hence, if the United States wanted to tax Japanese cars on a broad basis, this would involve taxing transplant production as well as imports. Placing a tax on transplant production, however, is at best complicated and at worst probably infeasible. In principle, the United States could renegotiate its tax treaty with Japan to effectively alter the taxes paid by the transplants. These taxes, however, are not directly based on sales; rather, they are based on accounting profits (i.e., they are not a per-unit production tax). Furthermore, the tax treaty is not industry specific, so any changes to the treaty in order to try to tax transplant auto production would also possibly affect all Japanese direct investment. Tax treaties seem too blunt a tool.

Suppose, then, that the United States restricts potential tariffs to nameplates not made in the United States. Imports of these Japanese nameplates totaled about 855,000 in the 1994 calendar year. ${ }^{3}$ Of these, about one-quarter were models with retail prices in excess of $\$ 30,000$. (There were thirteen Japanese models in 1994 with base prices above about $\$ 30,000$.) In terms of revenue (as opposed to number of cars), these Japanese luxury models accounted for almost 40 percent of the value of imports. There were no Japanese cars with base prices in excess of $\$ 30,000$ produced in the United States. Japanese luxury cars, then, were an easily targeted and at least potentially effective group of products on which to place a tariff.

Seen from a different angle, Japanese automobile producers had, by 1994, done a very effective job of insuring themselves against tariffs by the United States. While the more expensive models were still produced in Japan, the models with the largest sales were also produced in the United States.

Faced with a bilateral trade deficit that was viewed as troubling by politicians, ${ }^{4}$ the United States opted for threatened tariffs on a limited set of cars in order to promote, among other things, an agenda of trade promotion in the automobile parts sector. Whether the threatened tariffs would actually benefit American OEMs depended on the substitution patterns of consumers. They would, however, almost certainly hurt Japanese OEMs, and therein lay the threat. The next step in analyzing the policy is to estimate the likely consequences of a tariff on Japanese luxury cars, and this is the topic of the next section.

3. Actual imports were higher since this figure does not include imports of nameplates made in both the United States and Japan. That is, imports of the Honda Accord and Toyota Camry, among many others, are not included here.

4. In this paper, I take it as given that the bilateral trade deficit was a topic of concern. From an economic viewpoint, this is not obviously sensible, but it seemed to constitute the political reality at the time. 


\subsection{The Threatened Tariffs, Their Estimated Consequences, and the Resulting Trade Promotion}

\subsubsection{Policy Details}

On 16 May 1995, President Clinton announced 100 percent tariffs on thirteen Japanese luxury cars to go into place four days later, with the sanctions becoming final on 28 June. This schedule gave Clinton and his trade representative, Mickey Kantor, a few weeks to see if brinksmanship might prove a successful strategy for trade promotion.

The details of the announced tax involved a 100 percent tariff on the landed cost of the following thirteen models: the Lexus (Toyota) LS400, SC400, GS300, SC300, and ES300; the Infiniti (Nissan) Q45, J30, and I30; the Acura (Honda) Legend and 3.2TL; the Mazda 929 and Millenia; and the Mitsubishi Diamante. Of these models, the Millenia had the lowest base price $(\$ 26,435)$, while the LS400 was the most expensive $(\$ 51,680)$. None of these cars sold in especially large quantities, although the Legend and the ES300 were the most popular by a factor of almost two. Slightly under 40,000 of each sold in 1994 . This compares with sales of about 365,000 for the Honda Accord alone.

Although the news media treated the tariff as if it would simply double the price consumers paid, this was simplistic and incorrect. The tariff would apply to the price that obtained in equilibrium after the tariff was imposed, and there is no reason to believe that the equilibrium price would be invariant to a tariff. Also, the 100 percent figure referred to the landed price, not the list price. What this figure translates to as a percentage of list price varies by model, but the leading trade publication, Automotive News, reported the tariff, as a percentage of list price, to be about 65 percent in the case of the Lexus LS400. For example, the landed value of this particular model was estimated to be $\$ 33,280$, while the dealer invoice was about $\$ 42,000$, and the list price was $\$ 51,680 .{ }^{5}$ In the analysis in this paper, an ad valorem tariff of 65 percent is used, although this figure is admittedly approximate and in reality would vary by model.

\subsubsection{Modeling the Policy}

In order to model the equilibrium that would obtain in the presence of the proposed tariff, one must model both consumer behavior and firm behavior. The basic setup is taken from Berry, Levinsohn, and Pakes (1995a). For purposes of brevity, an intuitive discussion of these methods is given here, and the interested reader is referred to Berry, Levinsohn, and Pakes (1995a) for a (much!) more in-depth discussion.

The model estimated has two parts-a utility-based consumer framework

5. Consumers also pay a 10 percent luxury tax on the portion of the price above $\$ 32,000$. 
on the demand side and a cost-function-based model of a multiproduct oligopolistic firm on the supply side. Each is discussed in turn.

Following a strategy developed by Pakes (1986), demand in this model is computed by aggregating over simulated heterogeneous consumers. Consumers' utility functions are assumed to have the same functional form, but the parameters of the function vary across the population. This is because consumer tastes vary throughout the population. The distribution of tastes is one of the primitives that is estimated. I assume that tastes for product attributes such as horsepower, weight, and size are normally distributed in the population. The estimation procedure estimates the mean and variance of these normal distributions. Price is treated a bit differently than other product attributes. I assume that sensitivity to price is inversely proportional to income and that it is income that varies throughout the population. Rather than estimating the distribution of income as, say, the distribution of taste for horsepower is estimated, the empirical distribution of incorne is used. There is also a random idiosyncratic component to utility. A simulated consumer, then, consists of a draw from each of the distributions of tastes and income as well as a draw from the distribution of idiosyncratic terms. This simulated consumer then chooses either to buy a car or to spend nothing and instead buy the "outside good." The utility of the outside good is normalized to zero, and its presence allows substitution out of the automobile market. Conditional on this set of draws, one can then compute which product gives this simulated consumer the greatest utility. One can imagine simulating about 90 million consumers (the number of households in the United States), hence effectively simulating the demand for automobiles. One would keep track of the most preferred product of each of these consumers and aggregate up to compute market shares. Loosely speaking, the objective of the estimation procedure is to find the means and variances of the underlying distribution of tastes that come as close as possible to fitting the observed market shares.

The description given above ignores many important aspects of the demand side of the model. These include econometric issues such as allowing for product characteristics that are unobserved by the econometrician but observed by the consumer, the probable correlation of these unobserved characteristics with price and the econometric endogeneity thus induced, and sampling techniques (in particular, importance sampling). The role of the distribution of idiosyncratic tastes and how this interacts with ensuing policy analysis are also mostly omitted. These issues are discussed in BLP.

On the supply side of the model, each product is assumed to be produced with constant returns to scale, and a (log) marginal cost function is estimated for each product. Marginal cost is assumed to depend on attributes of the product as well as cost shifters such as wages and exchange rates (when applicable). The firms are modeled as multiproduct oligopolists who set prices in a Nash fashion (i.e., Bertrand competition). That is, firms set prices to maximize firmlevel profits, taking as given the prices of their competitors. To compute the 
prices that maximize profits, firms make use of information on demand elasticities. In a no-tax equilibrium, price is composed of marginal cost plus the markup. Since the demand system is not a constant elasticity system, markups will depend on quantities demanded (i.e., demand elasticities vary along the demand schedule). The demand and pricing sides of the model are simultaneous because demand depends on prices and the prices set by the firms depend on quantity demanded. Put another way, a firm's first-order conditions for optimal prices depend on demand elasticities, and the underlying (indirect) utility function itself depends on the prices that firms charge. The pricing and utility sides of the model are estimated simultaneously.

Modeling the 100 percent tax involves changing the firm's first-order condition and recomputing an equilibrium under the assumption that firms still maximize profits, that consumers still maximize utility, but that there is now a wedge between the price consumers pay and the price firms receive for a subset of products. ${ }^{6}$ In this case, that wedge is assumed to be an ad valorem tax of 65 percent of the producer price that obtains in the new equilibrium.

\subsubsection{Data and Results}

The model is estimated using twenty years of annual data from 1975 to 1994. ${ }^{7}$ Product attributes entering the utility function of consumers are a constant, the ratio of horsepower to weight, size (defined as length times width of the car, a dummy variable for whether the base model of the car had air conditioning as standard, and a dummy variable if it was made by a non-U.S. based company (i.e. foreign). Recall that for each of these attributes, the mean of the distribution of tastes for the attribute as well as the variance of this distribution is estimated. A parameter on the price term is also estimated. Prices are given in constant terms and the list price is used. For a discussion of the issues surrounding the use of list versus transaction price, see Berry, Levinsohn, and Pakes (1995b).

On the cost side, marginal cost shifters are a constant, the logs of horsepower divided by weight, size, the lagged exchange rate, wages, a dummy variable for air conditioning as standard, a trend term, dummy variables for Japan and Europe, and these dummy variables interacted with the trend term.

Table 1.2 gives the estimated parameters of the primitives of the model. The top panel gives the means of the distribution of tastes for the product attributes entering the demand side. The second panel gives the estimated standard deviations of these distributions. A large and precisely estimated standard deviation $(\sigma)$ may be interpreted as capturing heterogeneity in the population concerning how the attribute contributes to utility. A demand side attribute in this model

6. An additional assumption is that the set of products that firms produce does not change. Just how reasonable this assumption may be is discussed below.

7. The data set is available on request as a MIME attachment to email. Send requests to James $\mathrm{L}$ (amich.edu. 
Table 1.2

Estimated Parameters of the Demand and Pricing Equations: 2,470 Observations

\begin{tabular}{lrc}
\hline Variable & Parameter Estimate & Standard Error \\
\hline Demand-side parameters: & & \\
Mean $(\beta$ 's): & & \\
Constant & -6.697 & 1.046 \\
HP/weight & 1.414 & 1.095 \\
Size & 4.689 & .463 \\
Air & .934 & .194 \\
Foreign & -4.317 & .611 \\
Standard deviations $\left(\sigma_{\beta}{ }^{\prime}{ }^{\prime}\right):$ & & \\
Constant & 2.191 & 1.445 \\
HP/weight & 3.320 & 1.688 \\
Size & 1.295 & .907 \\
Air & .739 & .791 \\
Foreign & 5.774 & .579 \\
Term on price $(\alpha):$ & & \\
( $(\gamma / p)$ & 46.728 & 5.336 \\
Cost-side parameters: & & \\
Constant & -2.172 & .686 \\
ln(HP/weight) & .564 & .072 \\
ln(size) & 1.190 & .122 \\
Air & .482 & .040 \\
Trend & -.008 & .006 \\
Japan & -1.299 & 1.133 \\
Japan $\times$ trend & .016 & .012 \\
Euro & 3.363 & .493 \\
Euro $\times$ trend & -.034 & .006 \\
lag ln(e-rate $)$ & -.028 & .017 \\
ln(wage) & .895 & .159 \\
\hline
\end{tabular}

Note $: \mathrm{HP}=$ horsepower; $\mathrm{e}$-rate $=$ exchange rate.

is considered to be important if either its mean or its standard deviation is precisely different from zero. That is the case with all automobile attributes in this specification. Finally, although the mean of the distribution of taste for foreign cars is negative, it turns out that the elasticity of demand with respect to this dummy variable is indeed positive. This is because most of the consumers who place a negative value on foreign cars do not in fact buy a car.

The term on price is precisely estimated. Its implications for elasticities and hence markups are discussed below. All 2,470 products, however, face elastic demand at the estimated parameters.

Most marginal cost shifters are precisely estimated. The only estimated coefficients not significantly different from zero are those on the general trend, those on the lagged exchange rate, and those on the Japan dummy and interaction variables. All product attributes enter marginal cost positively and precisely.

Perhaps the easiest way to interpret the reasonableness of the estimated coef- 
Table 1.3

A Sample from 1994 of Estimated Price-Marginal Cost Markups of (Potentially) Taxed Models, Based on Table 1.1 Estimates

\begin{tabular}{lccc}
\hline & Price (\$) & $\begin{array}{c}\text { Markup (\$) } \\
\text { over MC } \\
(p-\mathrm{MC})\end{array}$ & $\begin{array}{c}\text { Fraction of } \\
\text { Markup }\end{array}$ \\
\hline Acura Legend & 33,800 & 8.048 & .351 \\
Acura Vigor & 26,350 & 5.965 & .334 \\
Infiniti Q45 & 50,450 & 12.988 & .380 \\
Infiniti J30 & 36,950 & 9.655 & .386 \\
Lexus ES00 & 31,200 & 7.925 & .375 \\
Lexus GS300 & 41,100 & 10.806 & .388 \\
Lexus LS400 & 51,200 & 13.164 & .380 \\
Lexus SC300 & 40,000 & 10.501 & .388 \\
Lexus SC400 & 47,500 & 12.285 & .382 \\
Mazda Millenia & 25,995 & 5.518 & .313 \\
Mazda 929 & 32,200 & 7.278 & .334 \\
Mitsubishi Diamante & 25,750 & 5.373 & .308 \\
\hline
\end{tabular}

Note $: \mathrm{MC}=$ marginal cost

ficients is to examine the markups that they imply since markups imply information about both marginal costs and underlying demand elasticities. The list price (in 1994 dollars) as well as the markup of twelve of the thirteen cars subject to the proposed tariff are given in table 1.3. One of the cars that would have been subject to the tax, the Infiniti I30, was not sold in 1994. Another of the cars, the Acura 3.2TL, was also not sold, but this car is basically a rebadged Acura Vigor, so the Vigor is used as a proxy for the 3.2TL. In table 1.3, one sees that the markups vary from about 30 percent of list price to about 38 percent. The more expensive models tend to have the higher percentage markups, suggesting that these models have relatively less elastic demand.

The estimates in table 1.2 above completely specify the underlying distribution of tastes in the population on the demand side of the model and the firm's first-order condition on the cost side. The model is an equilibrium model of the automobile market. Households are maximizing utility, while firms are simultaneously maximizing profits. Modeling the threatened tariff involves perturbing this equilibrium by altering the first-order conditions for the firms that produce the models subject to the tariff. One then recomputes the prices and quantities for which the new first-order conditions hold.

The main difference between the tariff and the no-tariff equilibria is that the tariff introduces a wedge between the price consumers pay and the price the firms receive. This wedge is taken to be 65 percent of the new equilibrium (post-tariff) producer price. Table 1.4 lists the twelve models targeted with tariffs that were sold in 1994. The first column lists the 1994 base model list price, while the second column lists the producer price that would obtain in the presence of the 65 percent tariff. These figures are surprising to those used 
Table 1.4

Prices with Implementation of the Threatened Tariff, Based on Table 1.1 Estimates

\begin{tabular}{lccc}
\hline & $\begin{array}{c}\text { Price }(\$) \\
\text { without Tariff }\end{array}$ & $\begin{array}{c}\text { Producer Price (\$) } \\
\text { with Tariff }\end{array}$ & $\begin{array}{c}\text { Consumer Price (\$) } \\
\text { with Tariff }\end{array}$ \\
\hline Acura Legend & 33,800 & 33,264 & 54,886 \\
Acura Vigor & 26,350 & 27,108 & 44,728 \\
Infiniti Q45 & 50,450 & 45,805 & 75,578 \\
Infiniti J30 & 36,950 & 35,053 & 57,837 \\
Lexus ES300 & 31,200 & 30,665 & 50,598 \\
Lexus GS300 & 41,100 & 38,311 & 63,213 \\
Lexus LS400 & 51,200 & 46,475 & 76,684 \\
Lexus SC300 & 40,000 & 37,391 & 61,695 \\
Lexus SC400 & 47,500 & 43,435 & 71,668 \\
Mazda Millenia & 25,995 & 27,195 & 44,872 \\
Mazda 929 & 32,200 & 32,313 & 53,317 \\
Mitsubishi Diamante & 25,750 & 27,111 & 44,733 \\
\hline
\end{tabular}

to thinking about taxes in models of perfect competition with a representative consumer. In those models, the tax burden is shared between the consumers and the firm, with burdens distributed according to relative elasticities. Those models, however, do not characterize the U.S. automobile market very well. The estimates of the producer price that would obtain with a 65 percent tariff show remarkably little price change as a result of the imposition of the tariff. The price received by producers falls in the cases of nine of the twelve models, although these declines are not large. The largest decline (relative to the notax price) is only about 9 percent. In three cases, the price received by producers actually rises. What is going on here?

There are three intertwined explanations. First, in models in which goods are strategic complements, a tax will tend to exert an upward influence on the price received by the producer. In a Bertrand model with linear demands, all goods are strategic complements. While the equilibrium concept assumed here is Bertrand, demand is not linear. It turns out that about half the product pairs are strategic complements. Hence, in these cases, a tariff shifts reaction functions out and tends to increase equilibrium prices. Whether the producer price will increase so much as to result in a producer price higher than the no-tariff price is an empirical issue. Second, in this model, consumers are heterogeneous. When the tariff is applied to some products, the consumers who substitute away from those products are the price-sensitive consumers. The consumers who continue to buy the car at the post-tariff price are those who have relatively inelastic demand for the taxed product. After the tariff, then, the firm faces a more inelastic demand for its product, and this will tend to move prices higher. Again, the magnitude of this influence is an empirical matter. Third, and this is closely related to the second factor, the idiosyncratic term in the utility function is assumed to have an extreme value ("logit") distribution. An 
empirical implication of this is that, at any price, there will be some consumers whose idiosyncratic tastes are such that a particular product is still bought. This phenomenon is not unique to the logit assumption. If the idiosyncratic term were normally distributed ("probit"), there would still be the occasional draw from the tail of the distribution. These draws from the tails of the unbounded distributions will give rise to at least some demand for every product at any price. This phenomenon will also tend to exert an upward influence on price. The relative importance of this (as well as ways around the problem) is the topic of continuing research. In summary, producer prices tend to fall a small amount, but this is not uniform across products.

With relatively unchanged producer prices, consumer prices with the tariff rise substantially. These prices are given in the last column of table 1.4. Most prices rise by about 60 percent. Hence, the price of the top-of-the-line Lexus sedan rises from $\$ 51,200$ to over $\$ 76,000$. The price of the top-of-the-line Infiniti Q45 also exceeds $\$ 75,000$. An important cautionary note is due here. The figures in table 1.4 assume that the firms continue to play a static Bertrand game and maximize prices accordingly. If news reports following the announcement of the threatened tariffs are to be believed, this is not a realistic assumption. Soon after the tariffs were announced, for example, Toyota stated that it would not change the price of the cars subject to the tariff. This implies that Toyota was prepared to absorb the $\$ 20,000-\$ 30,000$ tariff. As a longrun strategy, this probably could not be sustained. As a short-run strategy, it is somewhat puzzling, although presumably it helped placate their dealer network.

Although the producer prices of the taxed models did not increase substantially with the tax, the ensuing high consumer prices would have exacted a heavy toll on sales and profits. Table 1.5 addresses these issues. The first column gives the sales that actually occurred in the 1994 calendar year. Note that none of the models threatened with tariffs have very large sales. For purposes of comparison, almost 370,000 Honda Accords were sold during this period, and the corresponding number of the Ford Taurus was almost 400,000. Of the models listed in table 1.5, the least expensive Lexus (the ES300) had the highest sales, and these totaled just over 39,000. The second column in table 1.5 lists the variable profits associated with each model. This is just the producer price minus marginal cost (the markup) times sales. These numbers should be treated with some caution as it is not completely clear what constitutes variable profits in an industry with such huge fixed costs. Still, they provide a baseline for comparison. These figures suggest that, while sales are not huge, profits of some of these models are indeed quite substantial. The estimates imply that the Acura legend, the Lexus ES300, and the Lexus LS400 each earned a bit more than $\$ 400$ million for their respective parent firms. These large numbers are due to the significant markups on these models.

When the tariff was threatened, car dealers that sold the affected models claimed that sales would fall drastically should the tariff go into effect. My 
Table 1.5

Sales and Profits with Implementation of the Threatened Tariff, Based on Table 1.1 Estimates (sales are in 1,000s; profits are in $\$ 1,000,000$ )

\begin{tabular}{lccrr}
\hline & $\begin{array}{c}\text { Sales } \\
\text { without Tariff }\end{array}$ & $\begin{array}{c}\text { Profit } \\
\text { without Tariff }\end{array}$ & $\begin{array}{c}\text { Sales } \\
\text { with Tariff }\end{array}$ & $\begin{array}{c}\text { Profit } \\
\text { with Tariff }\end{array}$ \\
\hline Acura Legend & 35.709 & 424.277 & 9.836 & 111.598 \\
Acura Vigor & 8.469 & 74.582 & 1.952 & 18.665 \\
Infiniti Q45 & 11.949 & 229.092 & 3.896 & 56.597 \\
Infiniti J30 & 22.718 & 323.769 & 6.935 & 85.683 \\
Lexus ES300 & 39.108 & 457.476 & 10.671 & 119.119 \\
Lexus GS300 & 13.939 & 222.340 & 4.447 & 58.530 \\
Lexus LS400 & 22.443 & 436.140 & 7.299 & 107.354 \\
Lexus SC300 & 4.537 & 70.330 & 1.436 & 18.516 \\
Lexus SC400 & 7.392 & 134.052 & 2.391 & 33.643 \\
Mazda Millenia & 24.423 & 198.962 & 5.296 & 49.505 \\
Mazda 929 & 9.206 & 98.929 & 2.376 & 25.799 \\
Mitsubishi Diamante & 18.096 & 143.544 & 3.822 & 35.514 \\
\hline
\end{tabular}

estimates suggest that the dealers were right on target. With the imposition of the tariff, sales plummet. Sales of the taxed models fall, in aggregate, from about 218,000 to just over 60,000 . Although the decline in sales varies by model, most models see their sales fall around 75 percent. For example, Legend sales fall from 35,706 to 9,836, while those of the newly launched Mazda Millenia fall from 24,423 to 5,296. Hence, while producer prices remain mostly unchanged, the correspondingly high consumer prices drive demand way down. Profits accordingly fall. Again defined as the markup times sales, profits fall drastically. Declines are typically on the order of 75 percent. For example, profits from the Lexus LS400 fall from $\$ 436$ million to $\$ 107$ million. Profits from half the models subject to the tariff fall below $\$ 50$ million, and this raises the issue of whether these models will survive.

The new car industry is marked by tremendous fixed costs. If variable profits are too low, a model will not prove profitable to develop. With this sort of calculus in mind, it seems probable that, while the taxed models will not disappear immediately, the firms producing them may decide to discontinue some models when model change time comes. Making firm predictions would require detailed information on fixed costs, and such information is not readily available. Nonetheless, the issue of whether, say, Nissan will continue with its Infiniti line when the time comes for remodeling or whether they will develop new models when profits are so low is real.

Table 1.5 is useful for doomsayers who claimed that the proposed tariffs would really hurt the Japanese firms. That table, however, does not put the figures into any sort of firm-level perspective. The broader issue is whether the parent firms would be substantively hurt by the proposed tariffs. One might imagine that consumers who did not buy a Lexus might instead buy a top-of- 
Firm Profits by Country of Origin (in \$million), Based on Table 1.1 Estimates

\begin{tabular}{lrc}
\hline & Profits without Tariff & Profits with Tariff \\
\hline Total Japanese profits & $12,165.861$ & $10,638.131$ \\
Total U.S. profits & $34,572.571$ & $34,921.828$ \\
Total European profits & $3,852.204$ & $44,443.364$ \\
\hline
\end{tabular}

the-line Camry or Avalon (both Toyotas), hence diminishing the tariff's effect on Toyota. Another issue not addressed in the previous tables is who, if anyone, gains from these tariffs. It was widely speculated that the real beneficiaries of the proposed tariffs would be, not American firms, but rather European firms. This would be true if the consumers who substituted away from the taxed products instead bought the typically upscale European products.

Table 1.6 begins to address these issues. Rather than looking at one product at a time, the table looks at profits at a much more aggregate level. This table puts the likely effect of the threatened tariff in a broader context. Japanese profits fall by about $\$ 1.5$ billion, which represents a decline of approximately 12.5 percent. Whether this is a large decline depends on one's perspective. For a 100 percent tariff, one might argue that a 12.5 percent decline in profits is not that big. On the other hand, for a tariff as narrowly targeted as the one under consideration, a 12.5 percent overall decline might seem large. In any case, the proposed tariff would clearly hurt the Japanese firms. Who gains? The figures in table 1.6 suggest that the real winner would be the European firms. European profits increase by about 15 percent. U.S. profits are basically unaffected. Consumers who switch away from the targeted high-end Japanese cars tend to switch to other Japanese cars and European cars. According to my estimates, U.S. firms just do not win many new customers with the proposed tariffs. Furthermore, some of those customers who do switch to domestic cars are among the more price sensitive, and this works toward lowering markups.

\subsubsection{Actual Outcomes}

The previous section estimated what would have happened had the tariffs been put permanently into place. In fact, on 28 June 1995, about six weeks after the tariffs were first announced, they were withdrawn. This is consistent with the decline in Japanese profits in table 1.6, although political concerns were surely important.

The trade pact announced on 28 June affected many players in the U.S.Japan automobile market--U.S. parts producers, Japanese OEMs, U.S. OEMs, as well as retail dealerships. The effect of the agreement on each is discussed in turn.

The biggest winners of the trade pact were U.S. parts manufacturers. The net effect of the pact for parts makers is estimated to be a $\$ 9$ billion increase 
in Japanese purchases of parts from North American suppliers by $1998 .^{8}$ While some increase surely would have occurred naturally, the $\$ 9$ billion figure represents almost a 50 percent increase in parts purchases. The pledge to purchase more American parts bears much resemblance to a similar pledge obtained by President Bush in 1992. Recall that that agreement entailed a pledge to increase parts purchases by about $\$ 8.5$ billion. That pledge was met. There are, however, reasons to suspect that it will be harder to meet the pledged increase this time. When the previous pledge was announced, several Japanese OEMs had plans to build new transplant factories, the Japanese market share was increasing annually, and the yen was falling rather dramatically. All these factors facilitated meeting the earlier pledge. Now, only Toyota remains in an expansion mode in the United Sates, as other firms do not have major expansion projects in the works. ${ }^{9}$ Japanese market share seems to be leveling off, and few observers expect the yen to continue to decline at the rate seen from 1991 to 1995 . All this suggests that meeting the pledge may be more difficult this time around. On the other hand, as discussed in section 1.1 above, U.S. parts manufacturers seem to be adapting to working with Japanese OEMs, and this process will continue.

The specific parts of the trade pact dealing with increased parts purchases include commitments from Japan's Big Five (Toyota, Honda, Mazda, Mitsubishi, and Nissan) to buy $\$ 6.75$ billion more in parts from U.S. suppliers, meet NAFTA local content standards by 1998 , increase transplant production from 2.1 million in 1994 to 2.65 million in 1998, and import $\$ 6$ billion worth of foreign parts by $1997, \$ 2$ billion of which will come from the United States. Japan also agreed to a series of administrative changes that are expected to contribute to opening up Japan's market for replacement parts. These changes include an end to inspections not requiring welds or rivets (expect some regulation-induced technological progress in car repair!); eased standards for garages, which is expected to increase competition and hence increase demand for U.S.-made parts; a promise to further review the restrictive list of parts that can be replaced only by certified garages; removing shock absorbers, struts, power steering, and trailer hitches from the list; a promise to respond within thirty days to U.S. requests to remove a part from the list; and permitting a new class of garages that will specialize in brakes, transmissions, and mufflers.

Japanese OEMs were mostly affected by the parts pledges discussed above. As noted, these pledges may be difficult to fulfill. Japanese OEMs' production and sales were also mildly affected by the threat of sanctions. Lexus decreased June production by about five thousand units, although U.S.-bound production increased soon afterward. Infiniti also saw June production fall, only for that fall to be made up in July. Acura delayed the launch of its 3.2TL model by

8. Much of this section is drawn from reporting in Automotive News (3 July 1995).

9. Honda is also expanding, but these plans had been in progress long before the announced trade pact. 
two months owing to the sanctions. Mazda production had been cut before the sanctions were put into place and was not really affected by the sanctions, while Mitsubishi delayed its 1996 Diamante by six to eight weeks. In no case did the sanctions and resulting decrease in production result in unexpected shortages.

U.S. OEMs benefited mostly from potentially increased access to the Japanese market. The details suggest that, relative to the parts deal, this is pretty minor. For example, Ministry of International Trade and Industry (MITI) agrees to write all Japanese automobile dealers to tell them that they are free to sell foreign vehicles and to announce that pressure (from Japanese OEMs) not to sell such vehicles could violate Japan's competition laws. Japan also agrees to survey dealers for interest in selling foreign cars and pass the survey results on to U.S. OEMs. ${ }^{10}$

Car dealers in the United States that carried the models threatened with the tariffs were also big winners from the trade pact in the sense that they avoided a potential disaster. They are not big winners in the sense that they are left clearly better off than they were prior to the entire trade dispute. Had the tariffs been put into place, however, the estimates reported in the previous section suggest that sales would have plummeted and new models might not have been forthcoming.

What about enforcement and monitoring of the trade pact? The pact does not contain specific quotas, other numerical targets, or timetables for gauging progress. Nor are specific sanctions mentioned should pledges go unfilled. Rather, the United States and Japan agree to work to speed progress should matters move too slowly. In sum, monitoring and enforcement are minimal. It remains to be seen how important this might be.

\subsection{Conclusions}

The story of recent trade frictions between the United States and Japan in the automobile parts market goes as follows. Initially, there was not much trade as Japanese cars were made in Japan with mostly Japanese parts and the same was mostly true of North American cars. Most of what trade did exist consisted of U.S. imports of Japanese parts. U.S. OEMs had a very different relation with their parts suppliers than did Japanese OEMs. These differences contributed to a growing bilateral trade deficit in auto parts. In an effort to address this deficit, the U.S. threatened tariffs on thirteen Japanese cars. This might seem like a very indirect way to address the parts trade, but more direct avenues were either ineffective or too costly. The threatened tariffs would have resulted in drastically reduced sales of the thirteen models, and Japanese profits in total would have fallen around 12.5 percent, while the European firms would have captured

10. Estimates suggest that these changes will result in about two hundred more outlets for U.S. cars in Japan by 1997. It is not clear, however, on what this estimate is based. 
many of the lost Japanese sales. U.S. firms would have been pretty much unaffected by the tariffs. An unenforced trade pact resulted in which Japan agreed to buy substantially more U.S. parts and the United States agreed to drop the threatened tariffs. The pact is one of trade promotion, although it resulted from a threat of trade protection. As noted at the outset, the line between trade promotion and trade protection is thin indeed.

\section{References}

Automotive News. Various 1995 issues. Detroit: Crain Communications.

Berry, Steven, James Levinsohn, and Ariel Pakes. 1995a. Automobile prices in market equilibrium. Econometrica 63:841-90.

. 1995b. Voluntary export restraints on automobiles: Evaluating a strategic trade policy. Working Paper no. 5235. Cambridge, Mass.: National Bureau of Economic Research.

Mitsubishi Research Institute. 1987. The relationship between Japanese auto and auto parts makers. Tokyo. Mimeo.

Pakes, Ariel. 1986. Patents as options: Some estimates of the value of holding European patent stocks. Econometrica 54:755-84.

Womack, James P., Daniel T. Jones, and Daniel Roos. 1990. The machine that changed the world. New York: Harper Collins. 